\title{
THYROGLOBULIN LEVEL IN POSTMORTEM BLOOD SAMPLES AS A DIAGNOSTIC TOOL FOR CAUSE OF DEATH
}

\author{
$\mathcal{B} \mathcal{Y}$ \\ Abdelmonem G. Madboly, Eslam S. Metwally and Hesham A. Farag* \\ Forensic Medicine \& Clinical Toxicology Department, Faculty of Medicine, Benha University, Egypt, \\ * Consultant of Forensic Medicine, Ministry of Justice, Egypt
}

\begin{abstract}
There were many conflicting results about the significance of postmortem thyroglobulin (Tg) level as a biomarker in forensic diagnosis. This work aimed to assess the relation between postmortem blood Tg level and the cause of death. Sixty cadavers received at Cairo Department of Forensic Medicine (Zenhum Morgue), Egypt, were classified into two groups; $1^{\text {st }}$ group included 30 cadavers died by different types of asphyxia, and $2^{\text {nd }}$ group included 30 cadavers died by causes other than asphyxia. In all cases, right heart blood (RHB) and left heart blood (LHB) Tg levels were measured using chemiluminescence immunometric assay and thyroid tissues were histopathlogically examined. Thyroglobulin level was high in $76.6 \%$ of $1^{\text {st }}$ group cases and in $83.3 \%$ of $2^{\text {nd }}$ group cases. In fatal traumatic brain injury cases, there was a significant positive correlation between Tg level and survival period. The mean value of RHB Tg levels was higher than that of LHB Tg levels in both studied groups while Tg was high in all cases with skin discoloration as a sign of putrefaction regardless of the cause of death. In conclusion, thyroglobulin level is unreliable as a diagnostic tool for cause of death because it may be affected by postmortem changes.
\end{abstract}

Keywords: Thyroglobulin, postmortem, diagnostic tool, cause of death.

\section{INTRODUCTION}

Biochemical analysis of postmortem blood may help to evaluate pathological status and to determine the cause of death in forensic diagnosis (Ishikawa et al., 2008; Uemura et al., 2008; Maeda et al., 2011).

There are numerous studies conducted on human body fluids in the field of postmortem chemistry. Among these, the postmortem thyroglobulin levels are frequently encountered in the literature (Katsumata et al., 1984; Senol et al., 2008).

Thyroglobulin (Tg), a glycoprotein synthesized in normal or malignant thyroid 
follicular cells, is an important marker for residual or recurrent differentiated thyroid cancer (Cooper et al., 2009; Ahn et al., 2013). It is well known that under physiological conditions, $\mathrm{Tg}$ molecule is the substrate for the hormones triiodothyronine and thyroxine. Its function outside the thyroid gland is unknown. Under certain pathologic conditions, an increase in $\mathrm{Tg}$ concentrations in the blood can occur (Dressler and Mueller, 2006).

While some previous studies confirmed that Tg levels in the heart blood were high in cases of asphyxia by neck compression such as hanging, strangulation, and throttling, as confirmed by Senol et al. (2008) and Maeda et al. (2011), and in those with traumatic injuries to the head, as confirmed by Dressler and Mueller (2006). Other studies, however, recorded cases in which there were high $\mathrm{Tg}$ levels without such previous findings (Hayakawa et al., 2014).

For these conflicting results about the significance of $\mathrm{Tg}$ level in postmortem blood samples as a biomarker for diagnosis in forensic autopsy; this work was conducted to study the relation between thyroglobulin $(\mathrm{Tg})$ level in postmortem blood samples and the cause of death, to assess if $\mathrm{Tg}$ level in postmortem blood samples can be used in forensic practice as a reliable biomarker for diagnosis of certain causes of death, e.g. cases of asphyxia by neck compression, and those with traumatic brain injuries.

\section{SUBJECTS AND METHODS}

\section{Subjects:}

This study was carried out on 60 cadavers, on which medico-legal autopsies were conducted at Cairo Department of Forensic Medicine (Zenhum Morgue), Ministry of Justice, Egypt. The studied cases were classified into two groups:

The $1^{\text {st }}$ group included 30 cadavers who died due to different types of asphyxia especially fatal pressure on the neck (hanging, throttling and ligature strangulation).

The $2^{\text {nd }}$ group included 30 cadavers who died due to any causes other than asphyxia including fatal traumatic brain injury (TBI).

Exclusion criteria: (1) cases with any evidence of thyroid disorders, that may affect thyroglobulin (Tg) levels such as hyperthyroidism or thyroid cancer "diagnosed by medical history if any, gross examination and microscopic examination of thyroid tissue" (2) cases with a postmortem interval $>48$ hours, or those with signs of advanced putrefaction, and (3) cases in which samples cannot be collected such as infants, charred bodies and severely mutilated bodies. 
Immediately after arrival of cadavers to the morgue, external postmortem (PM) examination was done for each case included in the study to determine the PM interval. The PM intervals of all cases were within 48 hours, and the bodies were kept in cold storage at $4^{\circ} \mathrm{C}$. Fractionated blood samples showed that under these conditions, no breakdown of Tg occurred for up to 7 days (Muller et al., 1997).

In cases of fatal TBI, survival time was recorded from the hospital report of each case.

The study was approved by the local research ethical board of Faculty of Medicine, Benha University, Egypt. All results obtained from the subjects were registered in special sheets of study in which confidentiality was secured.

\section{Sampling:}

Two whole blood samples (each $3 \mathrm{ml}$ ), from right heart blood "RHB" and left heart blood "LHB" separately, were collected during forensic autopsy of each case included in the study. Blood samples were collected by the researchers. All samples used for measurement of $\mathrm{Tg}$ levels were collected within 48 hours of time of death. Samples were inserted immediately in vacationer tubes containing ethylene diamine tetra acetic acid (EDTA), placed on ice bag and then transported to the laboratory. In suspicious toxic deaths, toxicologi- cal analysis was done for expected toxins; this was done beside routine toxicological analysis for each case included in the study.

\section{Thyroglobulin level measurement:}

Thyroglobulin levels were measured by chemiluminescence immunometric assays technique, as described by (Bohuslavizki et al., 2000; Hayakawa et al., 2014). Using commercial kit IMMULITE ${ }^{\circledR} 2000$ Thyroglobulin (L2KTY2), Diagnostic Products Corporation, U.S.A., reference value = (0.73 - $84 \mathrm{ng} / \mathrm{ml})$ for male and female. The accepted standard value of elevated $\mathrm{Tg}$ level was $200 \mathrm{ng} / \mathrm{ml}$.

\section{Histopathological study of thyroid gland:}

To exclude any thyroid gland diseases that may affect Tg levels; thyroid tissue specimens were taken from all cadavers included in the study after they were totally or sub-totally removed from their location during autopsy. They were fixed in $10 \%$ neutral buffered formalin and were cut at $2-5 \mu \mathrm{m}$ thickness and were stained using the routine pathological technique "Haematoxylin and Eosin" stain (Dressler and Mueller, 2006; Senol et al., 2008). Any case with a diseased thyroid was excluded from the study.

\section{Statistical design:}

The collected data were tabulated and analyzed using statistical package for the 
social sciences (SPSS) version 16 for windows (SPSS Inc., Chicago, USA). Data were expressed as mean and standard deviation. Wilcoxon test, Mann Whitney U test and Spearman's correlation coefficient (rho) were used as tests of significance. The accepted level of significance in this work was stated at 0.05 , ( $\mathrm{P}<0.05$ was considered significant).

\section{RESULTS}

\section{Demographic data:}

The present work was carried out on 60 cases; the mean age of cases was $41.1 \pm 19.6$ years, ranging from three to 77 years, the majority $(61.7 \%)$ of them were males.

\section{Autopsy findings:}

\section{A. $1^{\text {st }}$ group:}

The present study showed that in 23 $(76.6 \%)$ cases, thyroglobulin $(\mathrm{Tg})$ levels of both RHB and LHB were higher than 200 $\mathrm{ng} / \mathrm{ml}$ \{all died due to fatal pressure of the neck (throttling, ligature strangulation and hanging)\}. The mean Tg levels of RHB was $4717.8(17.4-23716.2) \mathrm{ng} / \mathrm{ml}$, whereas that of LHB was $963.2(13.2-9423) \mathrm{ng} /$ $\mathrm{ml}$. The difference between them was statistically highly significant $(\mathrm{P}<0.001)$, as illustrated in table (1).

Table (1) : Thyroglobulin (Tg) levels ( $\mathrm{ng} / \mathrm{ml})$ of RHB and LHB in cadavers died from different types of asphyxia $(n=30)$.

\begin{tabular}{|c|c|c|c|c|c|}
\hline \multirow{2}{*}{ Type of asphyxia } & \multirow[b]{2}{*}{$\mathrm{n}$} & Tg level (RHB) & Tg level (LHB) & \multirow{2}{*}{$\begin{array}{c}\text { Wilcoxon } \\
\text { test }\end{array}$} & \multirow{2}{*}{$P$ value } \\
\hline & & Mean \pm SD & Mean \pm SD & & \\
\hline Smothering & 4 & $53.9 \pm 14.30$ & $25.5 \pm 7.2$ & 1.83 & 0.068 \\
\hline Choking & 3 & $138.1 \pm 00.9$ & $48.1 \pm 30.7$ & 1.07 & 0.27 \\
\hline Throttling & 9 & $5052.7 \pm 8470.7$ & $775.4 \pm 1387.7$ & 2.67 & $0.002 *$ \\
\hline Ligature strangulation & 6 & $6187.8 \pm 9496.6$ & $954.1 \pm 1304.6$ & 2.2 & 0.028 * \\
\hline Hanging & 8 & $7288.1 \pm 8827.4$ & $1993.3 \pm 3107.4$ & 2.52 & $0.012 *$ \\
\hline Total & 30 & $4717.8 \pm 7850.3$ & $963.2 \pm 1914.9$ & 4.7 & $<0.001 *$ \\
\hline
\end{tabular}

$\mathrm{n}=$ number, $\mathrm{RHB}=$ right heart blood, $\mathrm{LHB}=$ left heart blood, $\pm \mathrm{SD}=$ standard deviation, ${ }^{*}=$ significant at $\mathrm{P}<0.05$.

Skin discoloration due to putrefaction was observed in $12(40 \%)$ cases of the $1^{\text {st }}$ group upon external examination, and in all 12 cases $\mathrm{Tg}$ levels of both RHB and
LHB were above the standard value. The statistical differences of $\mathrm{Tg}$ levels were significant $(\mathrm{P}<0.05)$, as shown in figure (1). 


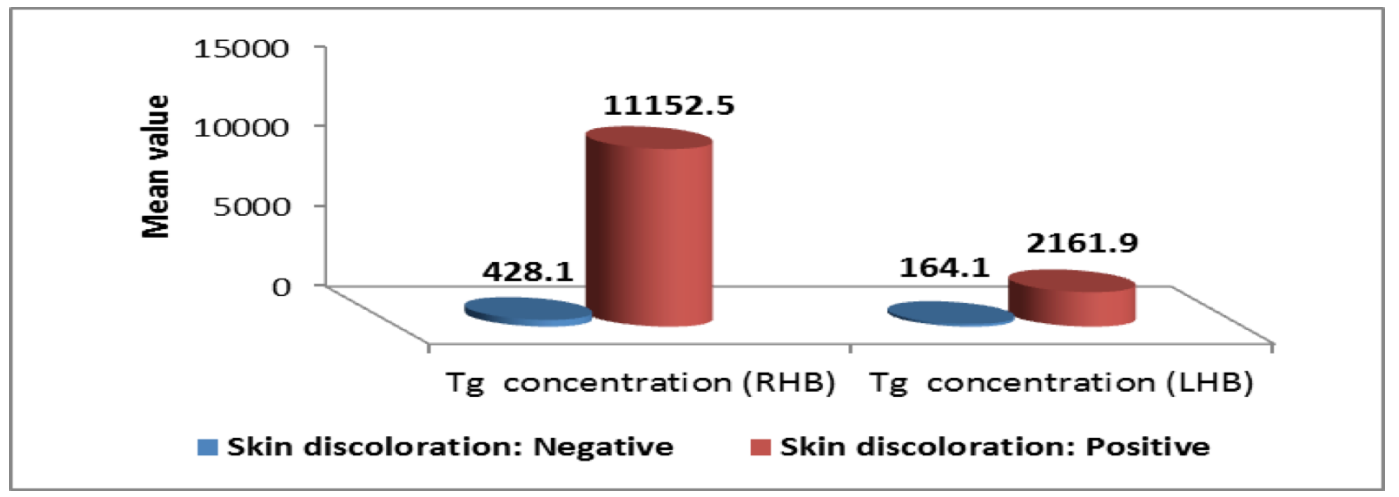

Fig. (1) : Relation between thyroglobulin level (Tg) in $\mathrm{ng} / \mathrm{ml}$ of RHB" right heart blood" and LHB "left heart blood" and skin discoloration as a sign of putrefaction among cadavers died from different types of asphyxia $(n=30)$.

The present study illustrated that cases with evidences of classical signs of asphyxia (congestion, cyanosis, petechial haemorrhages of the skin of the face), and those with severe neck pressure (assessed at autopsy by the presence of significant hemorrhages in the neck mus-

cles under the pressure mark and/or fractures of the laryngo-hyoid complex), had high $\mathrm{Tg}$ levels in both RHB and LHB, in comparison with the negative cases. These differences were statistically significant $(\mathrm{p}<0.05)$, as illustrated in table (2).

Table (2) : Relation between thyroglobulin (Tg) levels (ng/ml) of (RHB and LHB) and the presence of classical signs of asphyxia and severity of neck pressure detected during autopsy of the $1^{\text {st }}$ group $(\mathrm{n}=30)$.

\begin{tabular}{|c|c|c|c|}
\hline \multirow{2}{*}{ Parameter } & \multirow{2}{*}{$\mathbf{n}$} & Tg level (RHB) & Tg level (LHB) \\
\hline & & Mean \pm SD & Mean \pm SD \\
\hline \multicolumn{4}{|c|}{ Classical signs of asphyxia: congestion, cyanosis, petechial haemorrhages of the face } \\
\hline Negative & 11 & $2259.4 \pm 6027.7$ & $192.8 \pm 346.3$ \\
\hline Positive & 19 & $6141.1 \pm 8559.8$ & $1409.2 \pm 2295.3$ \\
\hline \multicolumn{2}{|l|}{ Mann Whitney U test } & 2.56 & 3.25 \\
\hline \multicolumn{2}{|l|}{$\mathrm{P}$ value } & $0.01 *$ & $<0.001 *$ \\
\hline \multicolumn{4}{|c|}{ Neck autopsy: significant hemorrhages in the neck muscles under the pressure mark: } \\
\hline Negative & 11 & $2154.9 \pm 6057.7$ & $165.5 \pm 350.4$ \\
\hline Positive & 19 & $6201.6 \pm 8518.4$ & $1425.1 \pm 2286.0$ \\
\hline \multicolumn{2}{|l|}{ Mann Whitney U test } & 3.21 & 3.21 \\
\hline \multicolumn{2}{|l|}{$\mathrm{P}$ value } & $0.001 *$ & $0.001 *$ \\
\hline \multicolumn{4}{|c|}{ Neck autopsy: Fractures of the laryngohyoid complex: } \\
\hline Negative & 19 & $2599.9 \pm 6152.1$ & $429.4 \pm 989.8$ \\
\hline Positive & 11 & $8376.1 \pm 9346.1$ & $1885.2 \pm 2719.3$ \\
\hline \multicolumn{2}{|l|}{ Mann Whitney U test } & 2.78 & 2.78 \\
\hline \multicolumn{2}{|l|}{$\mathrm{P}$ value } & $0.006 *$ & $0.006^{*}$ \\
\hline
\end{tabular}

$\mathrm{n}=$ number, $\mathrm{RHB}=$ right heart blood, $\mathrm{LHB}=$ left heart blood, $\pm \mathrm{SD}=$ standard deviation, ${ }^{*}=$ significant at $\mathrm{P}<0.05$. 
B. $2^{\text {nd }}$ group:

The present work confirmed that in 25 (83.3\%) cases, Tg levels of both RHB and LHB were higher than $200 \mathrm{ng} / \mathrm{ml}$. The mean Tg levels of RHB was 7679.7 (2.8 -
45865) $\mathrm{ng} / \mathrm{ml}$, whereas that of LHB was $1043.4(2.5-7530) \mathrm{ng} / \mathrm{ml}$. The difference between them was statistically highly significant $(\mathrm{P}<0.001)$, as illustrated in table (3).

Table (3) : Thyroglobulin (Tg) levels (ng/ml) of RHB and LHB in those died from causes other than asphyxia $(n=30)$.

\begin{tabular}{|c|c|c|c|c|c|}
\hline \multirow{2}{*}{ Cause of death } & \multirow{2}{*}{ n } & Tg level (RHB) & Tg level (LHB) & \multirow{2}{*}{$\begin{array}{c}\text { Wilcoxon } \\
\text { test }\end{array}$} & \multirow{2}{*}{ P value } \\
\hline & & Mean \pm SD & Mean \pm SD & & \\
\hline Traumatic brain injury & 8 & $8302.6 \pm 10390.1$ & $1373.3 \pm 1950.2$ & 2.38 & $0.017^{*}$ \\
\hline $\begin{array}{l}\text { Organophosphorus } \\
\text { poisoning }\end{array}$ & 5 & $47.1 \pm 15.9$ & $31.6 \pm 14.1$ & 1.98 & $0.049^{*}$ \\
\hline Stab wound & 12 & $11403.1 \pm 15260.7$ & $1515.7 \pm 2203.9$ & 3.06 & $0.002 *$ \\
\hline Gunshot injury & 5 & $5379.7 \pm 8729.0$ & $393.7 \pm 548.9$ & 2.02 & $0.043 *$ \\
\hline Total & 30 & $7679.7 \pm 11904.0$ & $1043.4 \pm 1781.5$ & 4.6 & $<0.001 *$ \\
\hline
\end{tabular}

$\mathrm{n}=$ number, $\mathrm{RHB}=$ right heart blood, $\mathrm{LHB}=$ left heart blood, $\pm \mathrm{SD}=$ standard deviation, ${ }^{*}=$ significant at $\mathrm{P}<0.05$.

Skin discoloration due to putrefaction was observed in $14(46.6 \%)$ cases of the $2^{\text {nd }}$ group upon external examination, and in all 14 cases Tg levels of both RHB and LHB were above the standard value. The statistical differences of $\mathrm{Tg}$ levels were significant $(\mathrm{P}<0.05)$, as shown in figure (2).

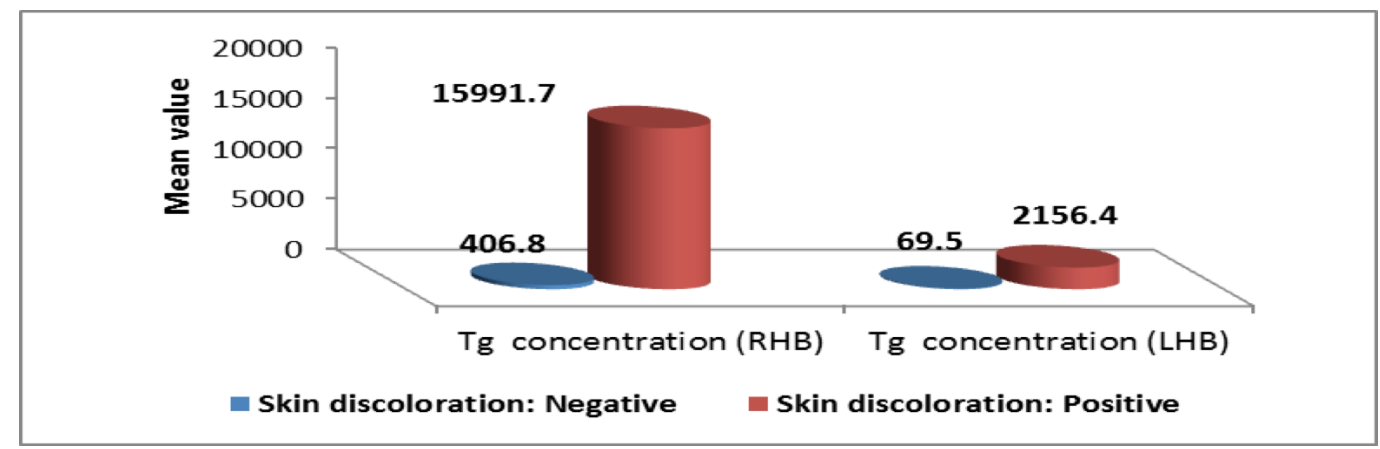

Fig. (2) : Relation between thyroglobulin level (Tg) in ng/ml of RHB" right heart blood" and LHB "left heart blood" and the skin discoloration as a sign of putrefaction among cases died from causes other than asphyxia $(n=30)$. 
In the studied cases of fatal traumatic brain injury (TBI) (eight cases), $\mathrm{Tg}$ levels of both RHB and LHB were above the standard value $(200 \mathrm{ng} / \mathrm{ml})$ in five $(62.5 \%)$ cases. There was a significant $(\mathrm{p}<0.05)$ positive correlation between $\mathrm{Tg}$ levels and the length of survival period of TBI cases, as shown in table (4).

Table (4) : Correlation between thyroglobulin (Tg) level (RHB and LHB) and the survival time of fatal traumatic brain injury (TBI) cases $(n=8)$.

\begin{tabular}{|l|c|c|c|c|}
\hline \multirow{2}{*}{ Traumatic brain injury } & \multicolumn{2}{|c|}{ Tg level (RHB) } & \multicolumn{2}{c|}{ Tg level (LHB) } \\
\cline { 2 - 5 } & rho & P & rho & P \\
\hline Survival time & 0.761 & $0.028 *$ & 0.736 & $0.038 *$ \\
\hline
\end{tabular}

$\mathrm{n}=$ number, $\mathrm{RHB}=$ right heart blood, $\mathrm{LHB}=$ left heart blood, rho $=$ Spearman's correlation coeffi cient,${ }^{*}=$ significant $(\mathrm{P}<0.05)$.

\section{Histopathological study of thyroid gland:}

The present work showed that in all cases included in the study either in the $1^{\text {st }}$ or the $2^{\text {nd }}$ groups, the histopathological examination of the thyroid gland revealed normal thyroid histological structure.

\section{DISCUSSION}

The present work included 60 cases ranging in age from three to 77 years, with a mean age of $41.1 \pm 19.6$ years; the majority $(61.7 \%)$ of them was males.

The present study showed that in 23 $(76.6 \%)$ of $1^{\text {st }}$ group cases who died due to fatal pressure of the neck (throttling, ligature strangulation and hanging); Tg levels of both RHB and LHB were higher than the standard level $(200 \mathrm{ng} / \mathrm{ml})$.
This was in accordance with Tamaki et al. (1987) who stated in their study, using enzyme-linked immunosorbent assay (ELISA) method for the measurement of blood Tg levels, that 12 (85.7\%) out of 14 cases of mechanical asphyxia (hanging, manual strangulation, ligature strangulation) showed plasma $\mathrm{Tg}$ levels higher than $200 \mathrm{ng} / \mathrm{mL}(2100 \pm 3450 \mathrm{ng} / \mathrm{ml})$. Also, Tamaki and Katsumata (1990) confirmed that plasma Tg levels in all of their studied victims of asphyxia $(n=42)$ were significantly higher than $200 \mathrm{ng} / \mathrm{ml}$. Later on, Senol et al. (2008) found that high Tg levels were encountered in 14 (58.3\%) out of 24 hanging cases.

The present study illustrated that cases with evidences of classical signs of asphyxia (congestion, cyanosis, petechial haemorrhages of the face), and those with severe neck pressure (assessed at autopsy 
of the neck by the presence of significant hemorrhages in the neck muscles under the pressure mark and/or fractures of the laryngohyoid complex), had high Tg levels in both RHB and LHB, in comparison with the negative cases.

Maxeiner and Bockholdt (2003) concluded that classical signs of asphyxia, in spite of being nonspecific, it is an indicator of prolonged agonal stage and vital reaction before death. Muller et al. (1997) stated that in the majority of asphyxial deaths, thyroid gland is more or less exposed to trauma and mechanical forces, and levels of the hormones and thyroglobulin secreted from this gland, are increased at the agonal stage.

In the present work, the direct proportion between $\mathrm{Tg}$ levels and severity of neck pressure was in agreement with Senol et al. (2008) who found in their study on 24 cases of hanging, that $\mathrm{Tg}$ level was progressively increased in relation to the severity of mechanical forces applied to the neck. They explained this by the fact that $\mathrm{Tg}$ as a glycoprotein synthesized and stored in normal thyroid follicular cells will be released into the circulation if the thyroid gland is squeezed by any mechanical force applied to the neck as in cases of fatal pressure on the neck.

The present study confirmed that in 25 (83.3\%) of the $2^{\text {nd }}$ group (cases died by different causes of death other than asphyxia); Tg levels of both RHB and LHB were higher than the standard level (200 $\mathrm{ng} / \mathrm{ml})$. This was in accordance with Hayakawa et al. (2014) who studied Tg level measured by the electrochemical luminescence immunoassay method (ECLIA) in 44 cadavers, excluding cases of asphyxia by neck compression, they found high $\mathrm{Tg}$ concentrations of both RHB and LHB in $43 \%$ of cases.

In the studied cases of fatal traumatic brain injury (TBI) (eight cases), Tg levels of both RHB and LHB were above the standard value $(200 \mathrm{ng} / \mathrm{ml})$ in five $(62.5 \%)$ of cases, and there was a significant positive correlation between $\mathrm{Tg}$ levels and the length of survival period of TBI cases.

This is in agreement with Dressler and Mueller (2006) who found raised Tg blood concentrations in about $57 \%$ of TBI studied cases. They also confirmed the presence of significant positive correlation between $\mathrm{Tg}$ concentrations and the length of survival period of TBI cases.

Marino and McCluskey (2000) stated that a latency period of at least 30 minutes must elapse between the TBI and the occurrence of death, before Tg markers can be detected. They assumed that a correlation exists, since the biosynthesis and secretion of $\mathrm{Tg}$ is regulated and controlled by centers in the hypothalamus and hy- 
pophysis (pituitary gland). Damage to these hierarchical structures through trauma causes disturbances in the feedback mechanism, so that an abnormal amount of $\mathrm{Tg}$ is secreted from the thyroid into the blood stream.

Another explanation of this positive correlation is that the hypophyseal necrosis, which is the main mechanism of postmortem elevation of Tg level in TBI cases, occurs always due to circulatory disturbances, which mainly occurs as a result of trauma and oligemic shock. This would require the lapse of a certain period of time between the trauma and the state of shock thus produced and the tissue response being actually observable (Sandtke et al., 2000; Dressler and Mueller, 2006).

Upon external examination, skin discoloration due to putrefaction was observed in $12(40 \%)$ cases of the $1^{\text {st }}$ group and in 14 $(46.6 \%)$ cases of the $2^{\text {nd }}$ group, in all of these cases, regardless of the cause of death, Tg levels of both RHB and LHB were above the standard value. There were highly significant differences of $\mathrm{Tg}$ levels in these cases and in cases without skin discoloration in both studied groups.

These findings were confirmed by Hayakawa et al. (2014) who detected high Tg concentrations (above the standard value) of the RHB and LHB in cases with evidence of skin discoloration due to decom- position, in contrast, in cases where no skin discoloration was detected, the $\mathrm{Tg}$ concentrations of both RHB and LHB were below the standard value. Based on this observation, they suggested that $\mathrm{Tg}$ concentrations increased as a result of postmortem changes.

In both studied groups, the mean value of RHB $\mathrm{Tg}$ levels was higher than the mean LHB Tg levels and the differences between them were more than $600 \mathrm{ng} / \mathrm{ml}$ in cases with positive skin discoloration, as a sign of putrefaction. In the studies done by Tamaki et al. (1987); Dressler and Mueller (2006); Tg level was measured using blood collected from the heart, without separating the RHB from the LHB. However, Tamaki and Katsumata (1990) in their study collected RHB and LHB separately and measured the $\mathrm{Tg}$ concentration in each sample; they found that the mean $\mathrm{Tg}$ concentration of RHB was significantly higher than that of LHB in cases both with and without neck compression. Later on Hayakawa et al. (2014) also found similar results in their study of 44 non asphyxia deaths. They explained the increase in $\mathrm{Tg}$ concentrations after death by the mechanism that $\mathrm{Tg}$ in the thyroid follicular lumen leaks into the vessels around the thyroid gland and diffuses into the circulation as postmortem changes progress. Therefore $\mathrm{Tg}$ spreads mainly through the veins, which retain blood volume more than arteries during the postmortem peri- 
od, producing significant differences between Tg levels of the RHB and LHB.

Histopathological examination of thyroid gland specimens, taken from all cases included in the study revealed normal thyroid structure. Tg levels are known to be high in cases of hyperthyroidism or differentiated thyroid cancer, whereas $\mathrm{Tg}$ is rarely secreted into the circulation in healthy individuals (Guyton and Hall, 2011).

\section{CONCLUSION AND RECOMMENDATIONS}

Thyroglobulin ( $\mathrm{Tg}$ ) level is unreliable as a postmortem diagnostic tool for the cause of death because the postmortem blood $\mathrm{Tg}$ level may be affected by many factors such as the severity of neck pressure in asphyxia deaths, the length of survival period in fatal TBI cases and the postmortem changes whatever the cause of death. It is necessary to collect RHB and LHB separately and measure their $\mathrm{Tg}$ levels individually when the Tg level is used as a biomarker for postmortem diagnosis of the cause of death.

\section{ACKNOWLEDGMENT}

Our deep gratitude to all staff members at Cairo Department of Forensic Medicine (Zenhum Morgue), and to all staff members of Forensic Medicine and Clinical
Toxicology Department, Faculty of Medicine, Benha University, Egypt, for their cooperation. www.fmed.bu.edu.eg. The valuable help of Dr. Rehab A. Hasan, Faculty of Medicine, Al-azhar University in histopathological study is gratefully acknowledged.

\section{REFERENCES}

Ahn, B.; Lee, W.K.; Jeong, S.Y.; et al. (2013): "Estimation of true serum thyroglobulin using simultaneous measurement of serum antithyroglobulin antibody". Int. J. Endocrinol., Article ID 210639, 7 pages, http: / / dx.doi.org/10.1155/2013/210639.

Bohuslavizki, K.H.; VomBaur, E.; Weger, B.; et al. (2000): "Evaluation of chemiluminescence immunoassays for detecting thyroglobulin ( $\mathrm{Tg}$ ) and thyroid peroxidase (TPO) autoantibodies using the IMMULITE 2000 system". Clin. Lab., 46 (1): 23-31.

Cooper, D.S.; Doherty, G.M.; Haugen, B.R.; et al. (2009): "Revised American thyroid association management guidelines for patients with thyroid nodules and differentiated thyroid cancer". Thyroid, 19 (11): 1167-1214.

Dressler, J. and Mueller, E. (2006): "High thyroglobulin ( $\mathrm{Tg}$ ) concentrations in fatal traumatic brain injuries". Am. J. Foren. Med. Pathol., 27 (3): 280-282. 
Guyton, A.C. and Hall, J.E. (2011): Textbook of Medical Physiology. $12^{\text {th }}$ ed. Philadelphia, Elsevier, P.P. 907-920.

Hayakawa, A.; Matoba, K.; Horioka, K.; et al. (2014): "Unreliability of the use of thyroglobulin concentration in postmortem blood samples in forensic diagnosis". Legal Med., 16: 164-167.

Ishikawa, T.; Hamel, M.; Zhu, B.; et al. (2008): "Comparative evaluation of postmortem serum concentrations of neopterin and C-reactive protein". Foren. Sci. Int., 179: 135-143.

Katsumata, Y.; Sato, K.; Oya, M. and Yada S. (1984): "Detection of thyroglobulin in bloodstain as an aid in the diagnosis of mechanical asphyxia". J. Foren. Sci., 29: $299-302$.

Maeda, H.; Ishikawa, T. and Michiue, T. (2011): "Forensic biochemistry for functional investigation of death: concept and practical application". Legal Med., 13: 5567.

Marino, M. and McCluskey, R.T. (2000): "Role of thyroglobulin endocytic pathways in the control of thyroid hormone release". Am. J. Physiol. Cell Physiol., 279: C1295-C1306.

Maxeiner, H. and Backholdt, B. (2003): "Homicidal and suicidal ligature strangu- lation - a comparison of the post mortem findings". Foren. Sci. Int., 137: 60-66.

Muller, E.; Franke, W.G. and Koch, R. (1997): "Thyroglobulin and violent asphyxia". Foren. Sci. Int., 90: 165-170.

Sandtke, S.; Saeger, W. and Hanke, D.K. (2000): "Pituitary necrosis decreasing incidence due to modern intensive therapy"? Pathol., 21 (4): 292-295.

Senol, E.; Demirel, B.; Akar, T.; et al. (2008): "The analysis of hormones and enzymes extracted from endocrine glands of the neck region in deaths due to hanging". Am. J. Foren. Med. Pathol., 29 (1): 49-54.

Tamaki, K. and Katsumata, Y. (1990): "Enzyme-linked immunosorbent assay for plasma thyroglobulin following compression of neck". Foren. Sci. Int., 44: 259-265.

Tamaki, K.; Soto, K. and Katsumata, Y. (1987): "Enzyme-linked immunosorbent assay for determination of plasma thyroglobulin and its application to postmortem diagnosis of mechanical asphyxia". Foren. Sci. Int., 33: 259-265.

Uemura, K.; Shintani-Ishida, K.; Saka, K.; et al. (2008): "Biochemical blood markers and sampling sites in forensic autopsy". J. Foren. Legal Med., 15: 312-317. 


\title{
مستوى الثيروجلوبيولين فى عينات الدم بعد الوفاة \\ كأداة لتشخيص سبب الوفاة
}

\author{
المشتركون فى البحث

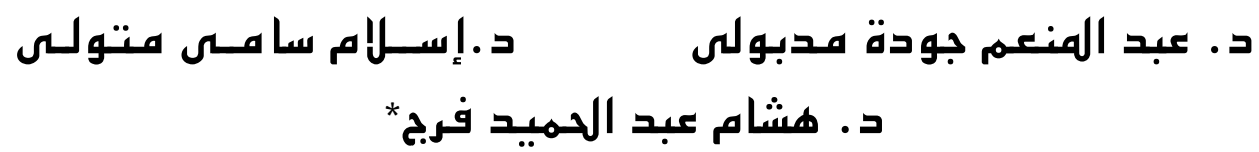 \\ قسم الطب الشرعى و السموم الأكلينيكية - كلية الطب - جامعة بنها - مصر \\ * | استشارى الطب الشرعى بوزارة العدل - مصر
}

يوجد العديد من النتائج المتضاربة حول أهمية وولالة مستوى الثيروجلوبيولين فى الدم بعد الوفاة كأداة لتشخيص سبب الوفاة في مجال

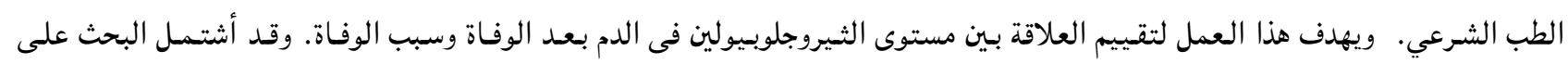
. 7 حالة من الوفيات التي وردت الى قسم الطب الشرعي بالقاهرة (مشرحة زينهم) ، وتم تصنيف هذه الحالات إلى مجموعتين، المجموعة الأولى

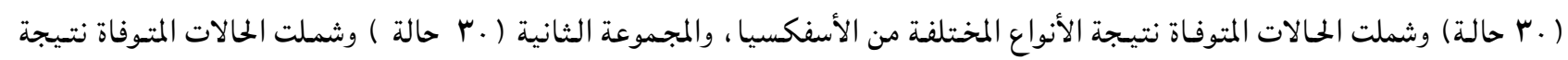
أسباب أخرى غير الأسفكسيا. وفي جميع هذه الحالات تم قياس مستوى الثيروجلوبيولين بالدم فى الجهة اليمنى واليسرى من القلب باستخدام تقنية التوهج الكيميائي، وقد تم فحص أنسجة الغدة الدرقية "هستولوجيا" لكل الحالات للتأكد من سلامتها و عدم وجود أسباب أخرى تؤثر

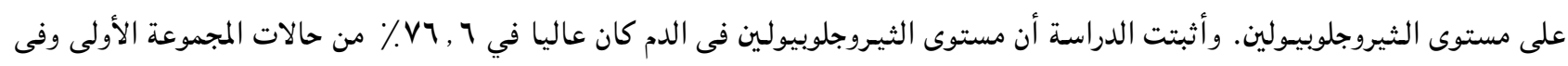

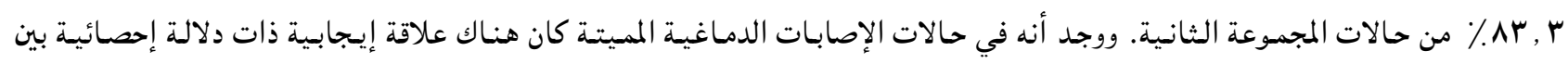
مستوى الثيروجلوبيولين بالدم وفترة البقاء على قيد الحياة بعـد الأصابة. ولقد كان متوسط مستوي الثيروجلوبيولين بالدم فى الجهة اليمنى من القلب أعلى من مستوي الثيروجلوبيولين بالدم فى الجهة اليسرى من القلب في كلا المجموعتين. وكان مستوي الثيروجلوبيولين عالي في جميع الحالات التى ظهر بها تلون بالجلد كدليل على التعفن بغض النظر عن سبب الوفاة. وقد خلصت الدراسة الى أن مستوى الثيروجلوبيولين بالدم لا يككن الاعتماد عليه كأداة تشخيصية لسبب الوفاة لأنه قد يتأثر بفعل التغييرات الرمية بعد الوفاة. 